\title{
High Heels - High Tech: \\ A Professional Development Opportunity for Educators
}

\author{
Betsy F. Willis, Ph.D. \\ School of Engineering, Southern Methodist University
}

\begin{abstract}
High Heels - High Tech is a 2-day professional development workshop for middle and high school educators, each of whom impact the lives of hundreds of girls annually. The workshop focuses on three themes: (1) the need for more women engineers, (2) preparation for college engineering, and (3) opportunities in engineering for women. Throughout the workshop, participants are immersed in the engineering experience as they learn from female engineers at corporate and university sites. Twenty educators attended the pilot workshop, and each educator serves a large, diverse student population. Workshop participants reported an increased knowledge of the field of engineering, an increased awareness of the opportunities in engineering, and how to prepare students for engineering. The impact of the workshop is expected to be three-fold: (1) increased interest among educators to participate in the workshop and (2) increased academic performance among students, and (3) increased interest in STEM careers among girls.

Introduction

Women control $80 \%$ of family purchase decisions, yet only $10 \%$ of working engineers are women. ${ }^{1,2}$ This disconnect between the creators and purchasers presents a great need for more female engineers to create products that will ultimately be purchased by women. Only $20 \%$ of B.S. degrees in engineering are awarded to women, $17 \%$ of M.S. degrees, and $12 \%$ of Ph.D. degrees. ${ }^{2}$ The lack of women entering the field of engineering can be traced back to the lack of female high school graduates prepared for and informed about engineering.
\end{abstract}

Few female high school students take the necessary classes in high school to enter college engineering, as shown in Table 1. ${ }^{3,4}$ 


\section{Table 1: Percentage of Students Completing Higher-Level Math and Science Courses in High School}

\begin{tabular}{|c|c|c|}
\hline \multirow[t]{2}{*}{ Course } & \multicolumn{2}{|c|}{$\begin{array}{c}\text { Percentage of } \\
\text { Students Completing } \\
\text { Course in High } \\
\text { School }\end{array}$} \\
\hline & Female & Male \\
\hline Calculus & $10.6 \%$ & $11.2 \%$ \\
\hline AP Calculus & $6.4 \%$ & $7.2 \%$ \\
\hline AP Biology & $18.0 \%$ & $14.5 \%$ \\
\hline AP Chemistry & $4.7 \%$ & $4.9 \%$ \\
\hline AP Physics & $2.1 \%$ & $4.0 \%$ \\
\hline Engineering & $6.5 \%$ & $7.1 \%$ \\
\hline $\begin{array}{l}\text { Biology, Chemistry, and } \\
\text { Physics }\end{array}$ & $23.7 \%$ & $27.4 \%$ \\
\hline
\end{tabular}

In all areas, except AP Biology, women complete higher-level math and science courses at a lower rate than male students. Assuming completion of the courses listed is necessary to be optimally prepared to enter college engineering, only $2 \%$ (physics being the lowest common denominator) of female high school graduates have the necessary background to enter college engineering. The lack of necessary preparation closes a door on opportunities to earn a B.S. degree in engineering which can lead to exciting careers in the engineering industry, business, law, and medicine.

Guidance counselors and teachers, specifically math and science, are key influencers of high school students when making academic and career choices. In Texas, guidance counselors must have a B.S. degree, three years of teaching experience, a M.S. degree in Counselor Education or Counselor Psychology, and certification as a "School Counselor" by the State Board for Educator Certification. Math and science teachers in Texas must have a B.S. degree from an accredited college or university, complete teacher training through an approved program, and complete the subject and grade level appropriate teacher certification tests. To maintain certification, guidance counselors must complete 200 hours of continuing education credits, and teachers must complete 150 hours $(1 \mathrm{credit}=1$ hour of instruction $)$ every 5 -year certification renewal cycle. ${ }^{5}$ Current continuing education opportunities include workshops, conferences, distance education, and independent study. These opportunities are offered by higher education institutions, Texas school districts, and education associations. Understanding the backgrounds and needs of guidance counselors, math teachers, and science teachers is necessary to provide high-quality, high-impact professional development opportunities that will enable them to help increase the number of women engineers.

The need for guidance counselors, math teachers, and science teachers is tremendous. The American School Counselor Association recommends an "ideal" guidance counselor to student ratio of 1:100 and a maximum ratio of 1:300. The Texas School Counselor Association recommends a ratio of 1:350, but ratios remain above this recommendation due to staffing and budget constraints. Texas will need over 82,000 new teachers within four years. ${ }^{5}$ The time guidance counselors have with each student is small, but the reach of each guidance counselor is 
great. In contrast, the time each math and science teacher has with each student is much greater. Therefore, educating guidance counselors, math teachers, and science teachers on the opportunities in and preparation for engineering has the potential to reach and impact a large number of students.

The need for more female engineers is great, and fulfilling this need requires reaching back into the middle and high schools to insure that girls have the proper academic background and knowledge of opportunities that a degree in engineering offers. Guidance counselors, math teachers, and science teachers are three of the primary influencers of girls on academic and career choices and are a key group to educate on the opportunities in and preparation for engineering.

\section{Goals, Key Messages, and Desired Outcomes}

High Heels - High Tech: Preparing Tomorrow's Engineers, provides continuing education to high school guidance counselors, math teachers, and science teachers to enable them to open doors of opportunity for women in the field of engineering. The goals of the professional development opportunity are tied to the key messages and measurable outcomes, Table 2.

Table 2: Goals, Key Messages, and Measurable Outcomes

\begin{tabular}{|c|c|c|c|}
\hline Goal of Educators & $\begin{array}{c}\text { Goal of Professional } \\
\text { Development }\end{array}$ & Key Message & $\begin{array}{c}\text { Measurable } \\
\text { Outcome }\end{array}$ \\
\hline $\begin{array}{l}\text { To expand higher } \\
\text { education and career } \\
\text { opportunities for } \\
\text { students }\end{array}$ & $\begin{array}{l}\text { To educate influencers } \\
\text { on what engineering is }\end{array}$ & $\begin{array}{l}\text { Engineering is } \\
\text { everywhere. }\end{array}$ & $\begin{array}{l}\text { Number of girls } \\
\text { pursuing college } \\
\text { engineering degrees }\end{array}$ \\
\hline $\begin{array}{l}\text { To provide incentive for } \\
\text { students to complete a } \\
\text { rigorous academic } \\
\text { curriculum }\end{array}$ & $\begin{array}{l}\text { To delineate high } \\
\text { school curriculum } \\
\text { required for college } \\
\text { engineering }\end{array}$ & $\begin{array}{l}\text { Higher-level math } \\
\text { and science courses } \\
\text { open doors. }\end{array}$ & $\begin{array}{l}\text { Number of girls } \\
\text { enrolled in AP math } \\
\text { and science } \\
\text { Number of girls } \\
\text { taking the AP exam } \\
\text { in these subjects } \\
\text { Number of girls } \\
\text { passing the AP } \\
\text { exam in these } \\
\text { subjects }\end{array}$ \\
\hline $\begin{array}{l}\text { To coordinate school } \\
\text { and community } \\
\text { resources for students, } \\
\text { parents, and teachers }\end{array}$ & $\begin{array}{l}\text { To connect influencers } \\
\text { with community and } \\
\text { industry resources on } \\
\text { engineering }\end{array}$ & $\begin{array}{l}\text { A support and } \\
\text { resource system on } \\
\text { opportunities in } \\
\text { engineering exists. }\end{array}$ & $\begin{array}{l}\text { Number of in-class } \\
\text { presentations on } \\
\text { engineering given } \\
\text { by invited speakers }\end{array}$ \\
\hline $\begin{array}{l}\text { To interpret results of } \\
\text { standardized testing }\end{array}$ & $\begin{array}{l}\text { To enable influencers } \\
\text { to identify students } \\
\text { with engineering } \\
\text { aptitude }\end{array}$ & $\begin{array}{l}\text { Engineering needs } \\
\text { all types of people. }\end{array}$ & $\begin{array}{l}\text { Standardized test } \\
\text { results in math and } \\
\text { science }\end{array}$ \\
\hline
\end{tabular}




\section{The Workshop}

The 2-day professional development workshop for educators provides hands-on, interactive, engaging instruction on the basics of engineering (the what, who, and how), college engineering programs, and preparing students for college engineering. The workshop first establishes a motivation for encouraging students to pursue engineering (Day 1 at Texas Instruments) and concludes with strategies to implement in participants' schools (Day 2 at SMU). Participants receive 13 CEUs.

Pre-workshop "homework" is assigned to raise the educators" awareness of the issues. The homework consists of two exercises:

- Interview an Engineer - Participants interview an engineer to learn the engineer's academic background, why he/she chose engineering, career path, and career goals. Participants may ask additional information if desired. Participants are asked to bring a summary of the interview in a pre-set format.

- Day without Engineers - Participants write a 1-page conceptualization of a day without engineers

Two 2-day workshops were held during the summer of 2004. Participants were recruited from middle and high schools throughout the DFW metroplex by working with the Region 10 Service Center of Texas Educators Association. The participants represented schools with diverse student populations, as shown in Table 3. 
Table 3: Diversity of Student Populations Served by Workshop Participants

\begin{tabular}{|c|c|c|c|c|c|c|c|c|}
\hline 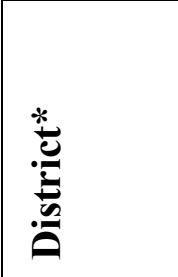 & $\begin{array}{l}\overline{8} \\
\bar{e} \\
\bar{e} \\
\text { nू }\end{array}$ & 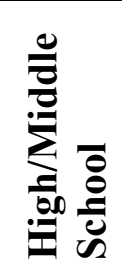 & & 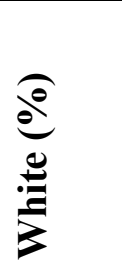 & $\frac{\varrho}{\frac{\partial}{e}}$ & 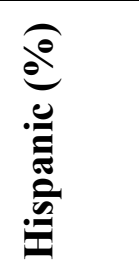 & $\underbrace{e}_{\substack{\frac{\pi}{2} \\
\frac{D}{2}}}$ & 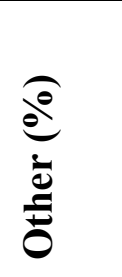 \\
\hline CFBISD & $\begin{array}{l}\text { Newman } \\
\text { Smith }\end{array}$ & HS & 2255 & $47 \%$ & $14 \%$ & $28 \%$ & $12 \%$ & $<1 \%$ \\
\hline DISD & Carter & HS & 1716 & $1 \%$ & $90 \%$ & $9 \%$ & $<1 \%$ & $<1 \%$ \\
\hline DISD & Skyline & HS & 4210 & $2 \%$ & $36 \%$ & $61 \%$ & $1 \%$ & $<1 \%$ \\
\hline DISD & Sunset & HS & 1918 & $3 \%$ & $3 \%$ & $93 \%$ & $<1 \%$ & $1 \%$ \\
\hline DISD & Hillcrest & HS & 1608 & $20 \%$ & $30 \%$ & $48 \%$ & $2 \%$ & $<1 \%$ \\
\hline DISD & $\begin{array}{l}\text { Woodrow } \\
\text { Wilson }\end{array}$ & HS & 1325 & $22 \%$ & $11 \%$ & $65 \%$ & $1 \%$ & $1 \%$ \\
\hline DISD & Anderson & MS & 759 & $<1 \%$ & $87 \%$ & $13 \%$ & $<1 \%$ & $<1 \%$ \\
\hline DISD & Marsh & MS & 1244 & $13 \%$ & $19 \%$ & $65 \%$ & $2 \%$ & $<1 \%$ \\
\hline DISD & Hood & MS & 1311 & $2 \%$ & $30 \%$ & $68 \%$ & $<1 \%$ & $<1 \%$ \\
\hline DISD & Seagoville & MS & 764 & $39 \%$ & $19 \%$ & $42 \%$ & $<1 \%$ & $<1 \%$ \\
\hline \multicolumn{4}{|c|}{ AVERAGE } & $17 \%$ & $34 \%$ & $49 \%$ & $4 \%$ & $1 \%$ \\
\hline
\end{tabular}

* CFBISD = Carrolton Farmers Branch Independent School District (suburban) DISD = Dallas Independent School District (urban)

All participating schools educate diverse populations of students. Therefore, reaching the educators in these schools is critical to increasing the number of underrepresented minorities pursuing degrees in engineering.

The unique facet of this workshop was the collaboration of industry, higher education, and K-12 education. Day 1 of each workshop was held at the Texas Instruments headquarters site, and Day 2 was held at SMU. Day 1 focused on what is engineering, what do engineers do on a dayto-day basis, and work in a corporate setting. Day 2 focused on college engineering and identifying students as potential engineers. Sessions were designed to be interactive among participants and speakers. A variety of speakers with various ethnicities and backgrounds served on panels, and nearly all of the speakers were female. Each day concluded with a tour. 
Evaluation

The workshop was evaluated by two methods: (1) pre- and post-workshop metrics and (2) a summative survey.

The pre- and post-workshop metrics were identical and measured the participants' learning in the workshop. Questions centered around college engineering prerequisites, potential careers within engineering, salaries of engineers, and the number of working female engineers. The postworkshop metric also included questions on what the educators planned to implement in their schools and classrooms to educate girls on the field of engineering.

The pre- and post-workshop metrics revealed that over half of the participants knew what math and science were required to enter college engineering prior to the workshop. The most dramatic increase in learning due to the workshop was the participants' knowledge of the career opportunities for engineers and engineers' salaries. Participants enthusiastically responded with strategies they hoped to implement in their classrooms and schools. Following are selected responses:

- Host guest speakers in classes

- Take students on field trips to engineering companies

- Distribute printed information on the importance of higher-level math and science as well as opportunities in engineering

- Talk with students about the opportunities in engineering

- Encourage students to pursue higher-level math and science

- Use Parent Night and Parent Conferences as venues to educate parents on the importance of higher-level math and science as well as opportunities in engineering

- Provide students and parents with information on SMU Engineering and scholarships

The summative survey asked participants to rate their experience in the workshop on a scale of one to five (with five being excellent). Questions included participants' satisfaction with the length, location, timing during the year, material presented and speakers. All items were rated as 4 or greater with the corporate location, TI, and the variety of speakers both received a rating of 5. Results from the summative survey were used to make logistical and content changes to future workshops. Perhaps the most telling evaluation was that participants expressed an interest in talking with their peers about the workshop.

The measurable outcomes listed in Table 2 with the workshop goals are tracked annually in conjunction with other studies.

Conclusion

High Heels - High Tech is a 2-day workshop for key influencers of females in grades 6-12: guidance counselors, math teachers, and science teachers. A partnership of industry and higher education brings engineering alive for the educators and to opens their eyes to the opportunities for their students. As shown by the participants' learning and feedback, the content of the workshop is much needed and is presented in an interesting, engaging manner. The greatest 
challenge yet remaining is the development of multiple formats varying in length and timing during the year to enable a greater number of educators to participate.

References

1) Speigel, Rob. "Report: Women Will Dominate Net Purchasing," E-Commerce Times. January 18, 2000.

2) Society of Women Engineering: http://www.swe.org/SWE/ProgDev/stats/stathome.html

3) U.S. Department of Education, National Center for Education Statistics, "The 1998 High School Transcript Study Tabulations: Comparative Data on Credits Earned and Demographics of 1998, 1994, 1990, 1987, and 1982 High School Graduates," NCES 2001-498, by Stephen Roey, Nancy Caldwell, Keith Rust, Eyal Blumstein, Tom Krenzke, Stan Legum, Judy Kuhn, Mark Waksberg, and Jacqueline Haynes. Project Officer, Janis Brown. Washington D.C. 2001.

4) U.S. Department of Education, National Center for Education Statistics, "High School and Beyond," First Follow-up survey; "1990 High School Transcript Study," "National Education Longitudinal Study of 1988," Second Follow-up survey; "1994 High School Transcript Study;" and "1998 High School Transcript Study." (This table was prepared February 2000.)

5) Texas Educators Association. www.tea.state.tx.us

Biographical Information

BETSY WILLIS, Ph.D.

Dr. Willis is a Director in the School of Engineering at Southern Methodist University where she leads the Gender Parity Initiative and Visioneering. Dr. Willis holds a Ph.D. in food process engineering from Purdue University. Dr. Willis has many television appearances and film performances to her credit, and she is a frequent contributor to books and other publications. 